\title{
Comparison of erythrocyte antioxidative enzyme activities between two types of haemoglobin $\mathrm{H}$ disease
}

\author{
S PRASARTKAEW, A BUNYARATVEJ, S FUCHAROEN,* P WASI* \\ From the Department of Pathology, Faculty of Medicine, Ramathibodi Hospital, and the *Department of \\ Medicine, Faculty of Medicine, Siriraj Hospital, Mahidol University Bangkok, Thailand
}

SUMMARY The activities of erythrocyte antioxidative enzymes were measured in two groups of patients with different genotypes of haemoglobin $(\mathrm{Hb}) \mathrm{H}$ disease: 21 with $\alpha$-thalassaemia 1 or $\alpha$-thalassaemia 2 ( $\alpha$-thalassaemia $1 / 2$ ) and 21 with $\alpha$-thalassaemia $1 / H b$ Constant Spring (HbCS). They were compared with 21 normal subjects. Both genotypes of $\mathrm{Hb} \mathrm{H}$ disease had increased activities of erythrocyte superoxide dismutase (SOD), glutathione peroxidase (GSH-Px), and catalase when compared with those of controls. Comparison of the two genotypes showed that subjects with $\alpha$-thalassaemia $1 / \mathrm{Hb}$ CS, the more severe disease, had higher SOD and GSH-Px activities but lower catalase activity than those with $\alpha$-thalassaemia $1 / 2$. This indicates that there are compensatory mechanisms in $\mathrm{Hb} \mathrm{H}$ erythrocytes to cope with increased generation of oxygen free radicals as a result of increased excess $\beta$ chain.

Autoxidation of haemoglobin can produce superoxide free radicals, which can cause red cell damage, leading to short red cell survival. Production of the superoxide is increased in the presence of isolated $\alpha$ or $\beta$ globin chains of the haemoglobin molecule. Haemoglobin $(\mathrm{Hb}) \mathrm{H}$ disease, one of the thalassaemia syndromes, is characterised by excess $\beta$ chains, which form relatively insoluble $\beta_{4}(\mathrm{Hb} \mathrm{H})$. This should lead to generation of an increased amount of superoxide. Evidence supporting this hypothesis is an increased erythrocyte superoxide dismutase (SOD) activity in $\mathrm{Hb} \mathrm{H}$ patients. ${ }^{1}$ SOD is an enzyme that catalyses the breakdown of superoxide into the less potent oxidant $\mathrm{H}_{2} \mathrm{O}_{2}$ and oxygen to lessen the oxidative damage to the cell. The $\mathrm{H}_{2} \mathrm{O}_{2}$; still capable of producing cell damage, is further reduced to water and oxygen by glutathione peroxidase (GSH-Px) and catalase. ${ }^{2}$

There are two common genotypes of $\mathrm{Hb} \mathrm{H}$ disease: one results from double heterozygosity between $\alpha$-thalassaemia 1 and $\alpha$-thalassaemia 2 genes $(\alpha$-thalassaemia) $1 / 2$ ), and the other from concomitant inheritance of $\alpha$-thalassaemia 1 and $\mathrm{Hb}$ Constant Spring genes $(\mathrm{HbCS})$. There are some differences between these two genotypes, with a greater proportion of red cells containing inclusion bodies, and higher levels of $\mathrm{Hb}$ Bart's and $\mathrm{Hb} \mathrm{H}$ being seen in the

Accepted for publication 2 June 1986
HbCS variety. ${ }^{3}$ These differences suggest that there might be different degrees of red cell oxidative stress and so we measured the activities of SOD, GSH-Px, and catalase in the red cells of the two types of $\mathrm{Hb} \mathrm{H}$ disease.

\section{Material and methods}

Sixty three subjects were examined, 21 with genotypes $\alpha$-thalassaemia $1 / 2,21$ with $\mathrm{HbCS}$, and 21 normal controls. The patients were from the files of the division of haematology, department of medicine, faculty of medicine, Siriraj Hospital; the normal controls were laboratory staff. The patients had received no blood transfusions for at least three months before examination. All of them were in steady state. Detailed clinical and laboratory findings of the patients have been reported previously. ${ }^{45}$ Informed consent was obtained from all subjects.

\section{HAEMATOLOGICAL STUDIES}

Red cell count, white cell count, mean corpuscular volume and haematocrit were determined in a Coulter counter, model ZF6. Haemoglobin concentrations were measured on a Coulter haemoglobinometer. Haemoglobin types were identified by starch-gel electrophoresis, using tris-edetic acid-borate buffer $(\mathrm{pH}$ 8.6). ${ }^{6}$ Quantitation of $\mathrm{Hb} \mathrm{A}_{2}, \mathrm{Hb} \mathrm{H}$, and $\mathrm{Hb}$ Bart's was performed by cellulose-acetate electrophoresis. ${ }^{7}$ 
PREPARATION OF HAEMOLYSATES FOR ENZYME ASSAY

The heparinised blood was centrifuged; plasma and buffy coat were removed by aspiration. Packed red cells were washed three times with ice cold isotonic buffer. Leucocytes and platelets were removed according to the method of Oski and Bowman. ${ }^{8}$ About a $20 \%$ red cell suspension was filtered through Whatman No 2 filter paper. The filtrate was collected, washed twice with 10 volumes of ice cold isotonic

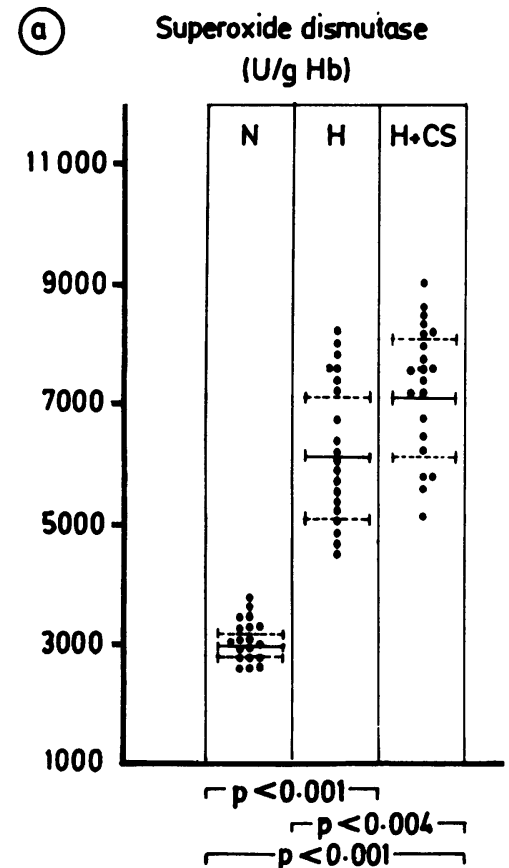

(b) Glutathione peroxidase

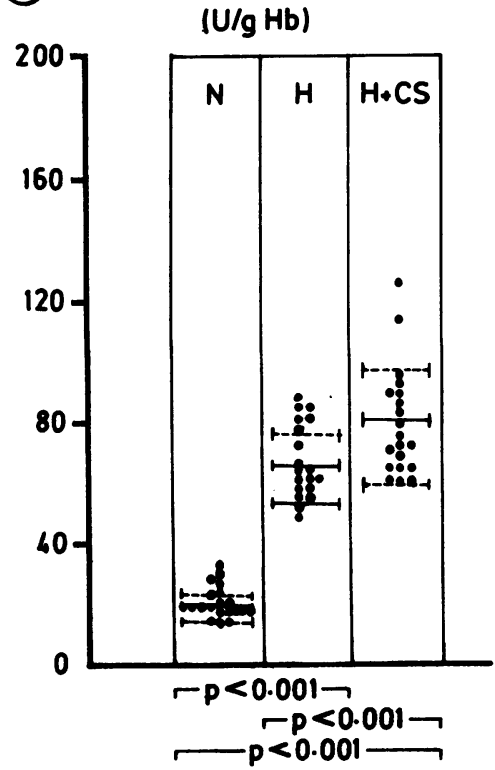

Superoxide dismutase (U/ml red blood cells)

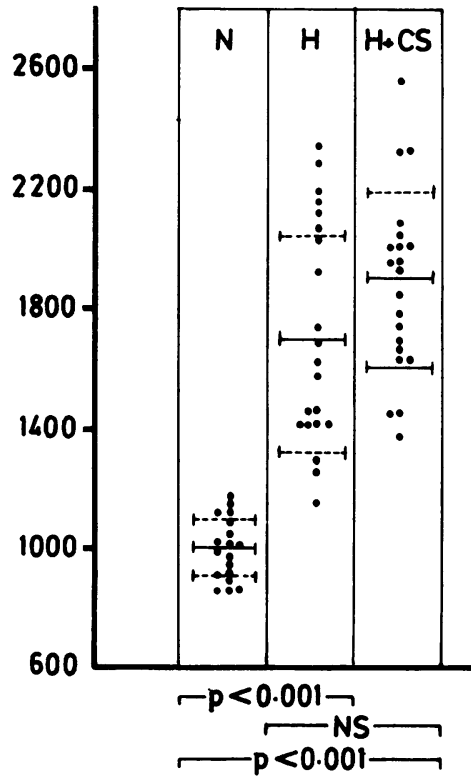

Glutathione peroxidase

(U/ml red blood cells)

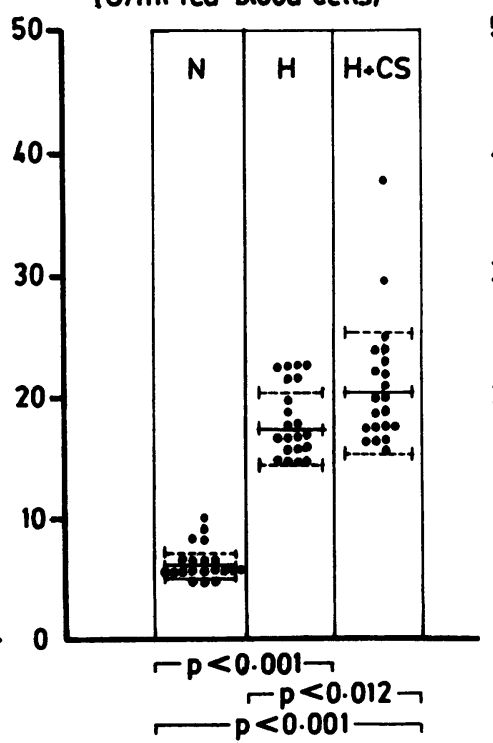

Superoxide dismutase (U/ $10^{10} / 1$ red blood cells)

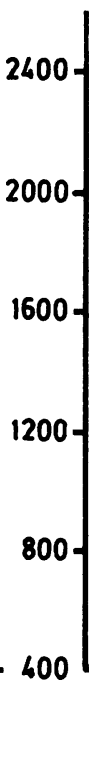



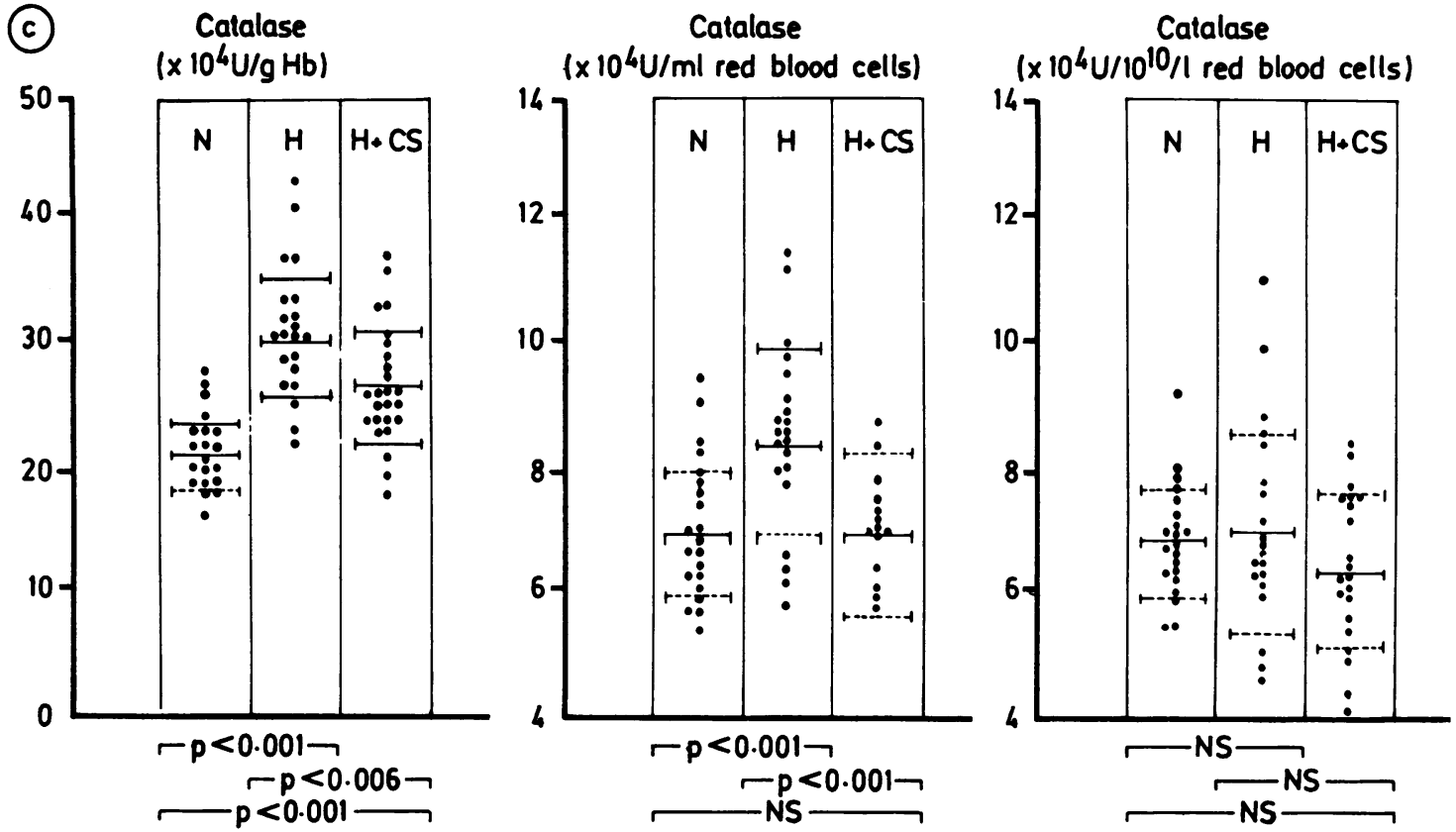

Activities of erythrocyte antioxidant enzymes (a) superoxide dismutase, (b) glutathione proxidase, and (c) catalase in normal subjects $(N)$, patients with $\alpha$-thalassaemia $1 / 2(H)$, and those with $H b C S(H+C S)$. Bars represent mean $(S D)$.

buffer, and resuspended to a $50 \%$ cell suspension. The cell suspension was haemolysed and assayed for SOD, ${ }^{9}$ GSH-Px, and catalase. ${ }^{10}$

\section{ENZYME ASSAYS}

The method for SOD measurement is based on the ability of the enzyme to inhibit the reduction of nitroblue tetrazolium by superoxide radical, which is generated by the reaction of photoreduced riboflavin and oxygen. ${ }^{9}$ Measurement of erythrocyte GSH-Px activity depends on the oxidation of NADPH by the oxidised form of glutathione (GSSG), which is generated by a catalytic reaction of GSH-Px. ${ }^{11}$ The method for measuring catalase activity is based on the ability of catalase to decompose hydrogen peroxide. ${ }^{12}$ Units of the enzyme assays were reported as $\mathrm{U} / \mathrm{g} \mathrm{Hb}, \mathrm{U} / \mathrm{ml}$ red blood cells, and $\mathrm{U} / 10^{10}$ red blood cells.

\section{Results}

Figs a-c show the results of SOD, GSH-Px, and catalase activities. Erythrocytes from both genotypes of $\mathrm{Hb} \mathrm{H}$ disease had higher SOD activities than the normal erythrocytes in all units determined. The $\mathrm{Hb}$ CS erythrocytes also had higher SOD activities than the $\alpha$-thalassaemia $1 / 2$ erythrocytes, but only on the basis of $\mathrm{U} / \mathrm{g} \mathrm{Hb}$ and $\mathrm{U} / 10^{10}$ red blood cells not $\mathrm{U} / \mathrm{ml}$ red blood cells.

Erythrocyte GSH-Px activity was higher in both genotypes when compared with normal values. GSH$\mathrm{Px}$ activity was also higher in $\mathrm{Hb} \mathrm{CS}$ erythrocytes compared with the values for $\alpha$-thalassaemia $1 / 2$ genotype in all respects.

Red cell catalase activity of $\alpha$-thalassaemia $1 / 2$ erythrocytes was higher than normal erythrocytes

Mean (SD) GSH-Px, catalase, and SOD, activities and concentrations of red cells in top and bottom layers

\begin{tabular}{lllll}
\hline Cell population & Reticulocyte count $(\%)$ & SOD $(\mathrm{U} / \mathrm{gHb})$ & GSH-Px $(I U / g \mathrm{Hb})$ & $\begin{array}{c}\text { Catalase } \\
\left(\times 10^{4} I U / g H b\right)\end{array}$ \\
\hline Top layer $(\mathrm{n}=6)$ & $5 \cdot 0(0.4)$ & $7214(826)$ & $65.09(7 \cdot 77)$ & $31 \cdot 52(0.81)$ \\
Bottom layer $(\mathrm{n}=6)$ & $1.8(0.3)$ & $6897(1120)$ & $63.72(4 \cdot 77)$ & $30 \cdot 96(3.06)$ \\
p value & $<0.001$ & NS & NS & NS \\
\hline
\end{tabular}


only when expressed as $\overline{\mathrm{U}} / \mathrm{g} \overline{\mathrm{H}} \mathrm{b}$ and $\mathrm{U} / \mathrm{ml}$ red blood cells, and catalase activity of $\mathrm{Hb}$ CS erythrocytes was statistically higher than normal only in $\mathrm{U} / \mathrm{g} \mathrm{Hb}$. The activity of catalase was higher in $\alpha$-thalassaemia $1 / 2$ than in $\mathrm{Hb} \mathrm{CS}$, expressed both as $\mathrm{U} / \mathrm{g} \mathrm{Hb}$ and $\mathrm{U} / \mathrm{ml}$ red blood cells. No statistical differences were found between the three groups when catalase activity was expressed as $\mathrm{U} / 10^{10}$ red blood cells.

To exclude the effect of excess young cells on enzyme activities whole blood from six patients was centrifuged and separated into top and bottom layers. Reticulocyte counts and the three enzyme activities were measured in both fractions (table). No significant differences in activities of all the studied enzymes were found between the top and the bottom layers.

\section{Discussion}

Red cells of patients with $\mathrm{Hb} \mathrm{H}$ disease contain excess $\beta$-globin chains that are unstable and polymerise to form $\beta_{4}$ inclusion bodies. Concentrations of $\mathrm{HbH}$ and the number of red cells containing inclusion bodies were greater in patients with the genotype of $\mathrm{Hb}$ CS compared with those with the genotype $\alpha$-thalassaemia $1 / 2 .{ }^{3}$ In addition, the distribution pattern of inclusion bodies was also different between the two genotypes. ${ }^{13}$ Our findings indicate that patients with the more severe disease, $\mathrm{Hb} \mathrm{CS}$, having a greater excess of $\beta$-globin chain, also have higher activities of SOD and GSH-Px but lower catalase activity than the milder genotype, $\alpha$-thalassaemia $1 / 2$.

Increased red cell SOD values in thalassaemic patients have previously been explained as a reaction to, or compensation for, the increased production of superoxide radicals, the amount of which is related to excess globin chain. ${ }^{1}$ Our results show that the greater increase in SOD activity is seen in $\mathrm{Hb}$ CS erythrocytes which have the highest numbers of red cell inclusions, the highest $\mathrm{HbH}$ concentrations, and the greatest clinical severity of the two genotypes.

The generally increased red cell GSH-Px activity in patients with $\mathrm{Hb} \mathrm{H}$ disease we describe has previously been reported. ${ }^{14}$ We found also that the values of GSH-Px are higher in the genotype $\mathrm{Hb}$ CS than the $\alpha$-thalassaemia $1 / 2$. The greater SOD activity in $\mathrm{Hb}$ $\mathrm{CS}$ erythrocytes probably generates a greater amount of $\mathrm{H}_{2} \mathrm{O}_{2}$, which in turn induces a compensatory rise in GSH-Px activity. An increase in red cell GSH-Px activity has been shown in vitro by the addition of acetylphenylhydrazine, an agent promoting release of superoxide radicals from haemoglobin. ${ }^{15}$

The $\mathrm{Hb}$ CS erythrocytes produce higher concentrations of $\mathrm{H}_{2} \mathrm{O}_{2}$ than $\alpha$-thalassaemia $1 / 2$ erythrocytes. This study shows significantly lower red cell catalase activity (although higher than normal sub- jects), in patients with the more severe form of the disease expressed both as per $\mathrm{g} \mathrm{Hb}$ and as per $\mathrm{ml}$ red blood cells. A possible explanation for lower red cell catalase activity found in the more severe genotype of $\mathrm{HbH}$ disease is that the greater amount of $\mathrm{H}_{2} \mathrm{O}_{2}$ might produce direct toxic damage to catalase. ${ }^{16}$ Although such damage can be prevented by NADPH, ${ }^{1617}$ the concentration of this is considerably reduced in conditions of high oxidative stress. In $\mathrm{Hb} \mathrm{CS}$ erythrocytes $\mathrm{H}_{2} \mathrm{O}_{2}$ is mainly detoxified to water and oxygen through the catalytic reaction of GSH-Px in which the GSH is simultaneously converted to GSSG. The GSSG is then reduced back to GSH by glutathione reductase, which requires NADPH. Decreased amounts of NADPH could result in insufficient protection of the toxic effect of $\mathrm{H}_{2} \mathrm{O}_{2}$ to catalase, leading to the lower activity of this enzyme.

This work was supported by the United States Public Health Research Grant (HL 34408) from the National Heart, Lung, and Blood Institute, United States of America.

\section{References}

1 Yenchitsomanus $P$, Wasi $P$. Increased erythrocyte superoxide dismutase activities in $\beta^{\circ}$-thalassemia/haemoglobin $E$ and in haemoglobin H diseases. $J$ Clin Pathol 1983;36:329-33.

2 Fridovich I. Superoxide dismutase. Ann Rev Biochem 1975;44:147-59.

3 Winichagoon P, Adirojnanon P, Wasi P. Levels of haemoglobin $\mathrm{H}$ and proportions of red cells with inclusion bodies in the two types of haemoglobin $\mathrm{H}$ disease. $\mathrm{Br} \mathrm{J}$ Haematol 1980;46:507-9.

4 Wasi P, Na-Nakorn S, Pootrakul S. The $\alpha$-thalassaemias. Clin Hematol 1974;3:383-410.

5 Wasi P, Na-Nakorn S, Pootrakul S, et al. Alpha- and betathalassaemia in Thailand. Ann NY Acad Sci 1969;165:60-82.

6 Gammack DB, Huchns EM, Gerald PS. Identification of the abnormal polypeptide chain of hemoglobin G-IB. J Mol Biol 1960;21:372-8.

7 Marergo-Rowe AJ. Rapid electrophoresis and quantitation of hemoglobins on cellulose acetate. J Clin Pathol 1965;18:790-2.

8 Oski FA, Bowman HA. A low Km phosphaenolpyruvate mutant in the Amish with red cell pyruvate kinase deficiency. $\mathrm{Br} J$ Haematol 1969;17:289-97.

9 Winterbourn GC, Hawkins RE, Brain M, Carrell RW. The estimation of red cell superoxide dismutase activity. $J$ Lab Clin Med 1975;85:337-41.

10 Beutler E, Blume KG, Kaplan JC, Lohr GW, Ramot B, Valentine WN. International Committee for Standardization in Haematology: recommended methods for red cell enzyme analysis. Br J Haematol 1977;35:331-40.

11 Armitage P. Statistical methods in medical research. Oxford: Blackwell Scientific Publications, 1971:398.

12 Beutler E. Red cell metabolism. A manual of biochemical methods. New York: Grune \& Stratton, 1975.

13 Bunyaratvej A, Sahaphong S, Bhamarapravati N, Wasi P. 
Different patterns of intraerythrocytic inclusion body distribution in the two types of haemoglobin $\mathbf{H}$ disease: an ultrastructural study. Acta Haematol 1983;69:314-8.

14 Beutler E, Matsumoto F, Powars D, Warner J. Increased glutathione peroxidase activity in $\alpha$-thalassaemia. Blood 1977;50:647-55.

15 Perona G, Guidi GC, Pica A, Cellerino R, Menna R, Zatti M. In vivo and in vitro variation of human erythrocyte glutathione peroxidase activity as a result of cell aging, selenium availability and peroxidase activation. Br J Haematol 1978;39:399-408.
16 Kirkman HN, Gaetani GF. Catalase: a tetrameric enzyme with four tightly bound molecules of NADPH. Proc Natl Acad Sci USA 1984;81:4343-7.

17 Eaton JW, Martin B, Etkin NJ. Catalase activity and red cell metabolism. In: Brewer GJ, ed. Advances in experimental medicine and biology. New York: Plenum Press, 1972:121-31.

Requests for reprints to: Dr A Bunyaratvej, Department of Pathology, Ramathibodi Hospital, Rama Road 6, Bangkok 10400, Thailand. 